\title{
Hubungan Pendidikan Dan Pekerjaan Dengan Kualitas Hidup Gay, Transgender, dan LSL
}

\author{
Resati Nando Panonsih ${ }^{1 *}$, Ika Artini ${ }^{2}$, Arif Effendi ${ }^{3}$, Putri Eka Permata ${ }^{4}$ \\ ${ }^{1)}$ Departemen Dermatologi dan Venereologi RS Pertamina Bintang Amin, dr_r3sati@yahoo.com \\ ${ }^{2}$ Departemen Farmakologi Fakultas Kedokteran Universitas Malahayati, ikaartini@malahayati.ac.id \\ ${ }^{3)}$ Departemen Dermatologi dan Venereologi Rumah Sakit Abdul Moeloek, arif.effendi62@yahoo.com \\ 4)Program Studi Kedokteran Fakultas Kedokteran Universitas Malahayati, putriekapermata@gmail.com
}

\begin{abstract}
ABSTRAK
Gay, Transgender dan Lelaki Seks Lelaki adalah individu yang mudah mengalami masalah baik itu masalah pada kesehatan maupun pada lingkungan sekitar seperti pada pendidikan dan pekerjaan sehingga akan mengganggu kehidupan mereka dan akan berdampak pada kualitas hidup mereka. Penelitian ini bertujuan untuk mengetahui hubungan antara pendidikan dan pekerjaan dengan kualitas hidup pada gay, transgender, dan lelaki seks lelaki di Bandar Lampung 2019. Penelitian ini merupakan penelitian survei analitik dengan pendekatan cross-sectional. Jenis data yang diperoleh yaitu data primer. Cara pengumpulan data melalui pembagian kuesioner WHOQOLBREF yang hasilnya akan dikategorisasikan. Penelitian ini dilakukan selama bulan September sampai November 2019. Pada penelitian ini sampel yang diambil meliputi seluruh anggota Organisasi Gaya Lentera Muda dengan jumlah 35 orang, diambil dengan teknik total sampling. Diketahui dari hasil penelitian kualitas hidup pada gay, transgender dan LSL di Bandar Lampung yang memiliki pendidikan menengah dengan kualitas hidup sedang sebanyak 12 responden (63,2\%) dan bekerja dengan kualitas hidup sedang sebanyak 12 responden (66,7\%). Hasil akhir menunjukkan bahwa terdapat hubungan yang bermakna antara pendidikan dan perkerjaan dengan kualitas hidup pada gay, transgender dan LSL di Bandar Lampung 2019 (p-value = 0,003 dan p-value = 0,414). Semakin tinggi tingkat pendidikan dan seseorang tersebut memiliki status bekerja maka semakin tinggi kualitas hidupnya.
\end{abstract}

Kata Kunci: Pendidikan, Pekerjaan, Kualitas Hidup, Gay, Transgender, LSL

\begin{abstract}
Gay, Transgender dan Men Who Have Seks With Men are individuals who are prone to problem both in health and in the environment such as education and work that will disrupt their lives and will have an impact on their quality of life. The study aim to know the relationship between education and occupation with the quality of life to the Gay, Transgender and MSM in Bandar Lampung 2019. The research using analytic survey with cross-sectional approach. The type of data obtained is primary data. The method of collecting data is by distributing questionnaires WHOQOL-BREF whose results will be categorized. This research was conducted from September to November 2019. In this research, the samples taken included all member of Gaya Lentera Muda organization with a total of 35 people, taken with total sampling technique. The report for quality of gay, transgender and MSM in Bandar Lampung who has middle education mostly have mild quality of life of 12 subjects $(63,2 \%)$ and the subjects who have occupation mostly have mild quality of life of 12 subject $(66,7 \%)$. The final results showed that there is a meaningful relationship between education and occupation with quality of life to gay, transgender and MSM in Bandar Lampung 2019 ( $p$-value =0,003 dan p-value =0,414). The higher the level of education and the person has a working status, the higher the quality of life.
\end{abstract}

Keywords : Education, Occupation, Quality of Life, Gay, Transgender, MSM

* Korespondensi Author: Resati Nando Panonsih, Departemen Dermatologi dan Venereologi Rumah Sakit Pertamina Bintang Amin, dr_r3sati@yahoo.com, Telp. 081227766689

\section{PENDAHULUAN}

Gay, Trasngender, Lelaki Seks Lelaki merupakan sebuah penyakit, atau masalah sosial yang menyimpang dari norma masyarakat, baik itu tata krama, budaya, agama maupun adat istiadat. Transgender adalah ketidaksamaan dari identitas gender yang diberikan kepada orang tersebut dengan jenis kelaminnya, dan seorang 
transgender bisa termasuk dalam orang yang biseksual, homoseksual, atau juga heteroseksual. ${ }^{1}$ Lelaki Seks Lelaki (LSL) merupakan laki-laki yang berhubungan seksual dengan laki-laki lainnya, tanpa memandang orientasi seksualnya atau identitas gender, dan apakah ia juga berhubungan seksual dengan perempuan. ${ }^{2}$

Menurut World Health Organization (2012), kualitas hidup didefinisikan sebagai persepsi individu terkait dengan kedudukan mereka di kehidupan dalam konteks sistem nilai dan budaya tempat mereka tinggal, dan berkaitan dengan tujuan, standar, ekspetasi dan fokus mereka dipengaruhi secara kompleks oleh keadaan psikologis, kesehatan fisik seseorang, hubungan sosial, tingkat kebebasan, keyakinan individu dan hubungan mereka dengan aspek penting dalam kehidupan individu tersebut. ${ }^{3}$

Menurut data Kementerian

Pemberdayaan Perempuan dan Perlindungan Anak Universitas Indonesia (2015) menunjukan prevalensi gay, di Amerika 20,8\% dan UK $16,3 \% .{ }^{4}$ Analisis populasi berdasarkan survey di Massachusetts, California dan USA $0,3 \%$ orang dewasa diidentifikasi sebagai transgender. Penelitian yang dilakukan di United Kingdom diperkirakan $0,6 \%$ orang-orang diatas umur 15 tahun diidentfikasi sebagai transgender. ${ }^{5}$ Menurut data UNAIDS menunjukkan bahwa prevalensi LSL di Australia pada tahun 2013 diperkirakan sebanyak 190.000 jiwa. $^{6}$

Di Indonesia jumlah gay sendiri diperkirakan 800.000 pada tahun 2010. Angka ini meningkat menjadi 3.000 .000 jiwa pada tahun 2012. ${ }^{7}$ Terdapat jumlah transgender pada tahun 2010 di 33 provinsi di Indonesia sebanyak 31.179 jiwa. $^{8}$ Berdasarkan estimasi Kemenkes pada 2012, terdapat 1.095.970 LSL baik yang tampak maupun tidak tampak. Lebih dari 5\% sekitar (66.180) mengidap HIV. ${ }^{1}$

Gay, transgender, dan lelaki seks lelaki di Bandar Lampung tergabung dalam sebuah organisasi dengan nama Gaya Lentera Muda (Gaylam) Lampung. Gaylam didirikan pertama kali pada tanggal 28 Oktober 2008. Dari hasil presurvey yang dilakukan pada hari Jum'at, 04 Oktober 2019 didapatkan data jumlah pengurus dan anggota organisasi Gaylam sebanyak 30-35 orang.

Gay, transgender, dan LSL sering menerima pandangan negatif, prasangka dan kebencian dari lingkungan, mereka juga mengalami penolakan, kekerasan, dan diskriminasi diberbagai area seperti pendidikan, pekerjaan, layanan kesehatan dan hak asasi mereka sehingga akan mempengaruhi kualitas hidup gay, transgender, dan lelaki seks lelaki tersebut. Penelitian Musliamin (2017) mendapatkan hasil bahwa terdapat hubungan yang signifikan antara tingkat pendidikan pada gay, transgender dan LSL. ${ }^{9}$ Penelitian Dwiwantika (2015) juga mendapatkan hasil bahwa terdapat hubungan status pekerjaan pada gay, transgender dan LSL. ${ }^{10}$ Kualitas hidup merupakan topik penting untuk dibahas karena mencakup keseluruhan aspek dari kehidupan manusia. Berdasarkan fakta dan teoru diatas, penulis tertarik untuk melakukan penelitian mengenai hubungan pendidikan dan pekerjaan dengan kualitas hidup gay, transgender, dan lelaki seks lelaki di Bandar Lampung 2019.

\section{METODOLOGI}

Jenis penelitian ini menggunakan pendekatan kuantitatif bersifat survei analitik yang bertujuan untuk menggali bagaimana hubungan pendidikan dan pekerjaan dapat mempengaruhi kualitas hidup seseorang. Kemudian melakukan analisis dinamika korelasi antara fenomena atau antara faktor risiko dengan faktor efek. ${ }^{11}$ Teknik sampel yang digunakan yaitu total sampling. Penelitian ini dilaksanakan pada bulan November 2019.

Populasi dalam penelitian ini adalah gay, transgender dan LSL yang terdaftar sebagai anggota di organisasi Gaya Lentera Muda Bandar Lampung. Dalam penelitian ini sampel yang diambil yaitu seluruh anggota organisasi Gaya Lentera Muda tersebut yang berjumlah 35 orang dengan menggunakan kuesioner WHOQOL-BREF yang dapat mengukur tingkat kualitas hidup seseorang.

Kuesioner WHOQOL-BREF ini terdiri dari 26 item pertanyaan yang berisi tentang aspek-aspek kualitas hidup, yaitu meliputi 
dimensi fisik, dimensi, psikologis, dimensi hubungan sosial dan dimensi lingkungan. Kuesioner ini terdiri dari dua bagian yang berasal dari kualitas hidup secara menyeluruh (pertanyaan nomor 1 dan 2) dan kesehatan secara umum. Semua pertanyaan berdasarkan pada Skala Likert lima poin (1-5). Instrumen ini juga terdiri atas pertanyaan positif, kecuali pada tiga pertanyaan yaitu nomor 3,4 , dan 26 yang bernilai negatif. Pada penelitian ini skor tiap domain (raw score) ditransformasikan dalam skala $0-100 .^{3}$

Pengambilan data dengan menggunakan kuesioner dilaksanakan di rumah kesekretariatan organisasi Gaya Lentera Muda yang didampingi langsung oleh peneliti. Gay, Trangerder dan LSL diberikan kuesioner dan menjawab pertanyaan yang terdapat dalam kuesioner tersebut. Hasil penilaian akan diakumulasikan dan dikategorikan apakah termasuk kualitas hidup tinggi, sedang atau rendah.

Teknik analisis data pada penelitian kuantitatif ini menggunakan uji univariate dan bivariat. Uji univariat digunakan untuk mencari distribusi dari pendidikan, pekerjaan dan kualitas hidup sedangkan uji bivariat pada penelitian ini dilakukan dengan uji statistik korelasi spearman. Uji statistik ini digunakan untuk mencari apakah terdapat hubungan antara dua variabel penelitian. Uji pada penelitian ini bertujuan untuk mengetahui hubungan pendidikan dan pekerjaan dengan kualitas hidup pada gay, transgender dan LSL.

\section{HASIL DAN PEMBAHASAN}

Penelitian ini dilakukan pada gay, transgender dan LSL yang termasuk dalam Organisasi Gaya Lentera Muda. Data penelitian yang digunakan adalah data primer dan didapatkan sampel sebanyak 35 responden.

\section{Hasil Analisis Univariat}

Berdasarkan Tabel 1 menunjukkan bahwa distribusi tingkat pendidikan, didapatkan pendidikan menengah sebanyak 19 responden $(54,3 \%)$ pendidikan dasar sebanyak 11 responden $(31,4 \%)$, dan pendidikan tinggi sebanyak 5 responden $(14,3 \%)$, sehingga total pada penelitian ini sebanyak 35 responden $(100 \%)$.

Tabel 1. Distribusi Tingkat Pendidikan, Status Pekerjaan dan Kualitas Hidup pada Gay, Transgender dan LSL di Bandar Lampung 2019.

\begin{tabular}{lcc}
\hline & Frekuensi & Persentase (\%) \\
\hline Tingkat & & \\
Pendidikan & & \\
\hline Dasar & 11 & 31,4 \\
Menengah & 19 & 54,3 \\
Tinggi & 5 & 14,3 \\
\hline$\quad$ Total & 35 & 100 \\
\hline Status Pekerjaan & & \\
\hline Bekerja & 18 & 51,4 \\
Tidak Bekerja & 17 & 48,6 \\
\hline$\quad$ Total & 35 & 100 \\
\hline Kualitas Hidup & & \\
\hline Rendah & 7 & 20 \\
Sedang & 19 & 54,3 \\
Rendah & 9 & 25,7 \\
\hline$\quad$ Total & 35 & 100 \\
\hline
\end{tabular}

Distribusi status pekerjaan, didapatkan responden yang bekerja sebanyak 18 responden $(51,4 \%)$ dan yang tidak bekerja sebanyak 17 responden $(48,6 \%)$, sehingga total responden pada penelitian ini sebanyak 35 responden (100\%). Distribusi kualitas hidup menurut WHOQOL-BREF, didapatkan kualitas hidup sedang sebanyak 19 responden (54,3\%), kualitas hidup tinggi sebanyak 9 responden (25,7\%), kualitas hidup rendah sebanyak 7 responden $(20,0 \%)$, sehingga total pada penelitian ini sebanyak 35 responden (100\%).

\section{Hasil Analisis Bivariat}

Analisis bivariat dilakukan dilakukan untuk mengetahui apakah terdapat hubungan yang signifikan antara dua variabel, dalam hal ini untuk mengetahui apakah terdapat hubungan antara pendidikan dan pekerjaan dengan kualitas hidup pada gay, transgender dan LSL di Bandar Lampung. Uji statistik yang akan digunakan pada penelitian ini Uji Korelasi Spearman. 
Tabel 2. Hubungan Tingkat Pendidikan dengan Kualitas Hidup pada Gay, Transgender dan LSL di Bandar Lampung 2019.

\begin{tabular}{|c|c|c|c|c|c|c|c|c|c|c|c|}
\hline & & \multicolumn{6}{|c|}{ Kualitas Hidup } & \multirow{2}{*}{\multicolumn{2}{|c|}{ Total }} & \multirow{3}{*}{$P$} & \multirow{3}{*}{$r$} \\
\hline & & \multicolumn{2}{|c|}{ Rendah } & \multicolumn{2}{|c|}{ Sedang } & \multicolumn{2}{|c|}{ Tinggi } & & & & \\
\hline & & $\mathrm{N}$ & $\%$ & $\mathrm{~N}$ & $\%$ & $\mathrm{~N}$ & $\%$ & $\mathrm{~N}$ & $\%$ & & \\
\hline \multirow{4}{*}{$\begin{array}{l}\text { Tingkat } \\
\text { pendidikan }\end{array}$} & Dasar & 7 & 63,6 & 3 & 27,3 & 1 & 9,1 & 11 & 31,4 & & \\
\hline & Menengah & 0 & 0 & 12 & 63,2 & 7 & 36,8 & 19 & 54,3 & 0,003 & 0,493 \\
\hline & Tinggi & 0 & 0 & 4 & 80,0 & 1 & 20,0 & 5 & 14,3 & & \\
\hline & Total & 7 & 20 & 19 & 54,3 & 9 & 25,7 & 35 & 100 & & \\
\hline
\end{tabular}

Berdasarkan Tabel 2 menunjukan bahwa hasil analisis uji spearman dengan tingkat kesalahan $5 \%$ menggunakan SPSS 20.0 didapatkan nilai $p=0,003$ dimana $p \leq 0,05$ menunjukkan Ho ditolak. Artinya, secara statistik terdapat hubungan antara tingkat pendidikan dengan kualitas hidup pada gay, transgender, dan LSL di Bandar Lampung 2019. Nilai koefisien korelasi sebesar 0,493 menunjukkan kekuatan korelasi sedang dan bersifat positif.

Selanjutnya untuk tabulasi silang dilihat bahwa pendidikan dasar dengan kualitas hidup rendah sebanyak 7 responden $(63,6 \%)$, kualitas hidup sedang sebanyak 3 responden (27,3\%), kualitas hidup tinggi sebanyak 1 responden $(9,1 \%)$, sehingga total responden dengan pendidikan dasar sebanyak 11 responden $(31,4 \%)$. Untuk pendidikan menengah dengan kualitas hidup sedang sebanyak 12 responden (63,2\%), kualitas hidup tinggi sebanyak 7 responden $(36,8 \%)$, sehingga total responden dengan pendidikan menengah sebanyak 19 responden $(54,3 \%)$. Untuk pendidikan tinggi dengan kualitas hidup sedang sebanyak 4 responden $(80,0 \%)$, kualitas hidup tinggi sebanyak 1 responden (20,0\%), sehingga total responden dengan pendidikan tinggi sebanyak 5 responden (14,3\%).

Tingkat pendidikan seseorang akan berpengaruh terhadap cara pandang, upaya meyelesaikan masalah, perilaku, dan gaya hidup. Latar belakang pendidikan akan berpengaruh pada sikap seseorang dalam mengambil keputusan di hidupnya. Selain itu, seseorang yang memiliki pendidikan yang tinggi dapat mengurangi kecemasan, sehingga dapat membantu individu dalam mengambil keputusan. ${ }^{12}$

Hasil penelitian diatas sejalan dengan penelitian yang dilakukan oleh Musliamin (2017) dimana dari hasil penelitian didapatkan di dalam pendidikan sekolah atau kampus, masyarakat berpendapat bahwa lesbi dan gay tidak seharusnya dilarang atau dipersulit mendapatkan akses pendidikan tetapi masyarakat melihat bahwa di sekolah banyak terjadi bullying ke siswa-siswa yang terduga lesbi dan gay dan pihak guru sepertinya tidak berusaha untuk menanganinya dan terkesan mendiamkan perbuatan buruk tersebut. Hal tersebut dapat menimbulkan ketidaknyamanan dalam lingkungan sekolah sehingga banyak dari mereka tidak melanjutkan pendidikan kejenjang berikutnya. ${ }^{9}$

Pendidikan akan mempengaruhi pengetahuan seseorang, pendidikan yang tinggi akan memiliki pengetahuan lebih luas sehingga akan lebih baik dalam menyelesaikan suatu masalah yang nantinya akan meningkatkan kualitas hidup 
Tabel 3. Hubungan Jenis Pekerjaan dengan Kualitas Hidup pada Gay, Transgender dan LSL di Bandar Lampung 2019.

\begin{tabular}{|c|c|c|c|c|c|c|c|c|c|c|c|}
\hline & & \multicolumn{6}{|c|}{ Kualitas Hidup } & \multicolumn{2}{|c|}{ Total } & \multirow{3}{*}{$\mathrm{P}$} & \multirow{3}{*}{$\mathrm{r}$} \\
\hline & & \multicolumn{2}{|c|}{ Rendah } & \multicolumn{2}{|c|}{ Sedang } & \multicolumn{2}{|c|}{ Tinggi } & \multirow[b]{2}{*}{$\mathrm{N}$} & \multirow[b]{2}{*}{$\%$} & & \\
\hline & & $\mathrm{N}$ & $\%$ & $\mathrm{~N}$ & $\%$ & $\mathrm{~N}$ & $\%$ & & & & \\
\hline \multirow{2}{*}{ Status Pekerjaan } & $\begin{array}{l}\text { Tidak } \\
\text { Bekerja }\end{array}$ & 7 & 41,2 & 7 & 41,2 & 3 & 17,6 & 17 & 48,6 & \multirow{2}{*}{0,014} & \multirow{2}{*}{0,414} \\
\hline & Bekerja & 0 & 0 & 12 & 66,7 & 6 & 33,3 & 18 & 51,4 & & \\
\hline & Total & 7 & 20,0 & 19 & 54,3 & 9 & 25,7 & 35 & 100 & & \\
\hline
\end{tabular}

Berdasarkan Tabel 3 menunjukkan bahwa hasil analisis uji spearman dengan tingkat kesalahan 5\% menggunakan SPSS 20.0 didapatkan nilai $p=0,014$ dimana $p \leq 0,05$ menunjukkan Ho ditolak. Artinya, secara statistik terdapat hubungan antara jenis pekerjaan dengan kualitas pada gay, transgender dan LSL di Bandar Lampung 2019. Nilai koefisien korelasi sebesar 0,414 menunjukkan kekuatan korelasi sedang dan bersifat positif.

Selanjutnya untuk tabulasi silang dilihat bahwa responden yang tidak bekerja dengan kualitas hidup rendah dan kualitas hidup sedang bernilai sama sebanyak 7 responden $(41,2 \%)$, kualitas hidup tinggi sebanyak 3 responden $(17,6 \%)$, sehingga total responden yang tidak bekerja sebanyak 17 responden (48,6\%). Responden yang bekerja dengan kualitas hidup sedang sebanyak 12 responden $(66,7 \%)$, kualitas hidup tinggi sebanyak 6 responden $(33,3 \%)$, sehingga total responden yang bekerja sebanyak 18 responden $(51,4 \%)$.

Bekerja merupakan kegiatan manusia untuk mengubah keadaan tertentu dari suatu alam lingkungan. Perubahan itu ditujukan untuk memenuhi kebutuhan hidup, mempertahankan hidup, dan memelihara hidup yang pada dasarnya semuanya untuk memenuhi tujuan hidup.Tujuan hidup melalui bekerja meliputi tujuan yang khusus dan pengelompokkan kerja yang menimbulkan rasa berprestasi (sense of accomplishment) dalam diri individu pekerja tersebut. ${ }^{13}$

Hasil penelitian di atas sejalan dengan penelitian yang dilakukan oleh Dwiwantika
(2015) dimana pada hasil penelitian didapatkan bahwa LGBT tidak diperbolehkan bekerja sebagai pekerja rumah tangga dan PNS. Pekerja rumah tangga tidak diperbolehkan karena akan berinteraksi langsung dengan keluarga mereka yang akan berinteraksi selama 24 jam karena mereka juga akan tinggal serumah. Terdapat juga yang melarang LGBT masuk dalam pemerintahan karena masuknya mereka kedalam pemerintahan menimbulkan anggapan dari kelompok mereka bahwa keberadaan mereka diterima oleh pemerintahan. Hal ini membuat mereka semakin percaya diri untuk semakin berkembang. Akan tetapi tidak menutup kemungkinan mereka dapat bekerja seperti banyak ditemui pada pekerja bank, pabrik, pekerja swasta, media, entertainment dan salon. Mereka diterima dengan baik asalkan tidak menunjukkan kemesraan dan mengganggu keharmonisan pekerja lainnya. $^{10}$

Pekerjaan memiliki peranan penting dalam mencukupi kebutuhan kehidupan dan seseorang yang bekerja memiliki produktivitas diri yang lebih sehingga akan meningkatkan kualitas hidup orang tersebut.

\section{KESIMPULAN DAN SARAN}

Berdasarkan hasil penelitian, analisis data, dan pembahasan penelitian Hubungan Pendidikan dan Pekerjaan dengan Kualitas Hidup pada Gay, Transgender dan LSL di Bandar Lampung 2019 dapat diambil kesimpulan sebagai berikut.

1. Diketahui sebagian besar distribusi tingkat pendidikan pada gay, transgender, dan LSL 
di Bandar Lampung 2019 adalah kelompok pendidikan menengah sebanyak 19 responden $(54,3 \%)$.

2. Diketahui sebagian besar distribusi status pekerjaan pada gay, transgender, dan LSL di Bandar Lampung 2019 adalah kelompok yang tidak bekerja sebanyak 17 responden $(48,6 \%)$.

3. Diketahui sebagian besar distribusi kualitas hidup pada gay, transgender dan LSL di Bandar Lampung 2019 adalah kualitas hidup sedang sebanyak 19 responden $(54,3 \%)$.

4. Diketahui terdapat hubungan yang bermakna antara tingkat pendidikan dengan kualitas hidup gay, transgender dan LSL di Bandar Lampung 2019 dengan nilai $p$ value $=0,003$ $(p \leq 0,05)$. Dan didapatkan nilai korelasi $\mathrm{r}=0,493$ yang artinya kekuatan korelasi pada penelitian ini adalah korelasi sedang dan mempunyai arah korelasi positif. Dapat disimpulkan bahwa semakin tinggi tingkat pendidikan maka semakin tinggi juga kualitas hidup seseorang.

5. Diketahui terdapat hubungan yang bermakna antara status pekerjaan dengan kualitas hidup gay, transgender dan LSL di Bandar Lampung 2019 dengan nilai $p$ value $=0,014$ $(p \leq 0,05)$. Dan didapatkan nilai korelasi $\mathrm{r}=0,414$ yang artinya kekuatan korelasi pada penelitian ini adalah korelasi sedang dan mempunyai arah korelasi positif. Dapat disimpulkan bahwa seseorang yang memiiki pekerjaan maka semakin tinggi kualitas hidupnya.

Hasil penelitian ini diharapkan dapat dijadikan acuan hubungan antara pendidikan dan pekerjaan dengan kualitas hidup pada gay, transgender dan LSL. Diharapkan pula peneliti selanjutnya dapat melakukan penelitian penelitian dengan jumlah sampel yang lebih banyak.

\section{UCAPAN TERIMA KASIH}

Peneliti mengucapkan terima kasih kepada Tuhan yang Maha Esa yang telah memberikan rahmat dan pertolongannya sehingga penelitian ini dapat berjalan dengan lancar. Peneliti juga mengucapkan terima kasih kepada semua pihak yang berperan dalam pelaksanaan penelitian ini, terutama kepada rekan-rekan Organisasi Gaya Lentera Muda Bandar Lampung sebagai responden dalam penelitian ini.

\section{REFERENSI}

1. Meluasnya LGBT (Lesbian, Gay, Biseksual, dan Transgender) Akibat Lemahnya Social Control Masyarakat. Dalam KemenSos RI; 2016 [dikutip 9 September 2019]. Tersedia pada:

http://puspensos.kemsos.go.id/home/breng/324

2. KemenKes RI. Pedoman Nasional Penanganan Infeksi Menular Seksual 2016. Jakarta: KemenKes RI; 2016.

3. World Health Organization. Programmed On Mental Health WHOQOL User Manual. Geneva: WHO; 2012.

4. KemenPPA RI. Pandangan Mahasiswa Terhadap Lesbian, Gay, Biseksual dan Transgender (LGBT) di Jakarta, Bogor, Depok dan Tangerang. Depok: Universitas Indonesia; 2015.

5. World Health Organization. HIV and Young Transgender People. Geneva: WHO; 2015.

6. Men Who Have Sex With Men: Population Size Estimate. Dalam UNAIDS; 2013 [dikutip 19 Maret 2020]. Tersedia pada: http://data.un.org/Data.aspx?d=UNAIDS\&f=inI D\%3A112

7. Yudianto. Fenomena Lesbi, Gay, Biseksual, dan Transgender (LGBT) di Indinesia Serta Upaya Pencegahannya. NIHZAM. 2016;5(1):63-74.

8. KemenSos RI. Kementrian Sosial Dalam rangka Pembangunan Kesejahteraan Sosial. Jakarta: Badan Pendidikan dan Penelitian Kesejahteraan Sosial.; 2012.

9. Musliamin. Eksistensi Komunitas Lesbian Gay Biseksual Transgender (LGBT) Di Kecamatan Kota Dalam Kabupaten Bone. Jurnal Hukum Keluarga Islam. 2017;3(2):180196.

10. Dadun, Dwiwantika Z. Pandangan Pekerja Terhadap Lesbian, Gay, Biseksual dan Transgender (LGBT) di Jabodetabek: Study Kualitatif Pengetahuan, Sikap, dan Praktek Pekerja Mengenai LGBT. RECONSTRA \& Kementrian Pemberdayaan Perempuan dan Perlindungan Anak Republik Indonesia (KPPPA RI); 2015. 
11. Notoatmodjo S. Metodologi Penelitian Kesehatan. Jakarta: Rhineka Cipta; 2014.

12. Muna IF, Fibriana AI. Kualitas Hidup Orang yang Pernah Menderita Kusta. 2019;3(4):568578.

13. Kurniawati ID. Masa Kerja dengan Jobengagement pada Karyawan. Jurnal Ilmiah Psikologi Terapan. 2014;2(2):311-324. 